\title{
Trends in the Management of Non-Vestibular Skull Base and Intracranial Schwannomas
}

This article was published in the following Dove Press journal:

Cancer Management and Research

Carlos Suárez, ${ }^{1,2}$ Fernando López, (iD) ${ }^{1-3}$ William M Mendenhall, ${ }^{4}$ Simon Andreasen, iD ${ }^{5-7}$, Lauge Hjorth Mikkelsen, (iD) ${ }^{7}$ Johannes A Langendijk, ${ }^{8}$ Stefano Bondi, (iD) 9 Juan P Rodrigo, ${ }^{1-3}$ Leif Bäck, iD ${ }^{10}$ Antti A Mäkitie, (iD ${ }^{10-12}$ Verónica FernándezAlvarez, (iD) ${ }^{13}$ Andrés Coca-Pelaz, (iD) ${ }^{1-3}$ Robert Smee, ${ }^{14}$ Alessandra Rinaldo, (iD) ${ }^{15}$ Alfio Ferlito (iD) ${ }^{16}$

'Instituto de Investigación Sanitaria del Principado de Asturias and CIBERONC, ISCIII, Oviedo, Spain;

${ }^{2}$ Instituto Universitario de Oncología del Principado de

Asturias, Universidad of Oviedo, Oviedo, Spain;

${ }^{3}$ Department of Otorhinolaryngology, Hospital

Universitario Central de Asturias, Oviedo, Spain;

${ }^{4}$ Department of Radiation Oncology, University of

Florida College of Medicine, Gainesville, FL, USA;

${ }^{5}$ Department of Otorhinolaryngology Head and Neck

Surgery and Audiology, Rigshospitalet, Copenhagen,

Denmark; ${ }^{6}$ Department of Otorhinolaryngology and

Maxillofacial Surgery, Zealand University Hospital,

Køge, Denmark; ${ }^{7}$ Department of Pathology,

Rigshospitalet, Copenhagen University Hospital,

Copenhagen, Denmark; ${ }^{8}$ Department of Radiation

Oncology, University Medical Center Groningen,

University of Groningen, Groningen, the Netherlands;

'Department of Otorhinolaryngology-Head and Neck

Surgery, San Raffaele Hospital, Vita-Salute University,

Milan, Italy; ${ }^{10}$ Department of Otorhinolaryngology -

Head and Neck Surgery, University of Helsinki, Helsink

University Hospital, Helsinki, Finland; "'Research

Program in Systems Oncology, Faculty of Medicine,

University of Helsinki, Helsinki, Finland; ${ }^{12}$ Division of

Ear, Nose and Throat Diseases, Department of Clinical

Sciences, Intervention and Technology, Karolinska

Institute, Karolinska Hospital, Stockholm, Sweden;

${ }^{13}$ Vascular Surgery Department, Hospital Universitario

Central de Asturias, Oviedo, Spain; ${ }^{14}$ Department of

Radiation Oncology, The Prince of Wales Cancer

Centre, Sydney, NSW, Australia; ${ }^{15}$ University of Udine

School of Medicine, Udine, Italy; ${ }^{16}$ International Head

and Neck Scientific Group, Padua, Italy

†'Simon Andreasen passed away on February 28 2020

Correspondence: Carlos Suárez

Instituto de Investigación Sanitaria del Principado de Asturias and CIBERONC, ISCIII, Avenida de

Roma s/n, Oviedo 330II, Spain

Email csuareznieto@gmail.com

Fernando López

Department of Otorhinolaryngology, Hospital

Universitario Central de Asturias, Avenida de

Roma s/n, Oviedo 330II, Spain

Email flopez_1981@yahoo.es

\begin{abstract}
The aim of this review is to analyze the latest trends in the management of nonvestibular skull base and intracranial schwannomas in order to optimize tumor control and quality of life. Non-vestibular cranial nerve schwannomas are rare lesions, representing $5-10 \%$ of cranial nerve schwannomas. Management decisions should be individualized depending on tumor size, location and associated functional deficits. Generally, large sized schwannomas exerting significant mass effect with increased intracranial pressure are treated surgically. In some cases, even after optimal skull base resection, it is not possible to achieve a gross total resection because tumor location and extent and/or to reduce morbidity. Thus, subtotal resection followed by stereotactic radiosurgery or fractioned radiotherapy offers an alternative approach. In certain cases, stereotactic radiosurgery or radiotherapy alone achieves good tumor control rates and less morbidity to gross total resection. Finally, given the slow growth rate of most of these tumors, observation with periodic radiographic follow-up approach is also a reasonable alternative for small tumors with few, if any, symptoms
\end{abstract}

Keywords: schwannoma, head and neck, cranial nerves, non-vestibular, skull base

\section{Introduction}

Schwannomas are primary peripheral nervous system tumors arising from Schwann cells. Schwann cells function to myelinate peripheral nerves beginning at the Obersteiner-Redlich zone, the transition from the central to the peripheral nervous system. ${ }^{1}$ They may originate from any peripheral, cranial or autonomic nerve. Schwannomas are usually solitary neoplasms; multifocal presentation should raise the suspicion for neurofibromatosis type 1 and type 2 or schwannomatosis. ${ }^{2}$

Sporadic non-vestibular cranial nerve schwannomas (NVCNS) are rare lesions, representing $5-10 \%$ of cranial nerve schwannomas. ${ }^{3}$ Nerve sheath tumors account for $8 \%$ of primary intracranial tumors and more than $90 \%$ of intracranial nerve sheath tumors are vestibular schwannomas (VS). ${ }^{4,5}$ In descending frequency, NVCNS involve the trigeminal nerve, lower CNs, the facial nerve and lastly the oculomotor nerves.

NVCNS are characterized by slow growth. It has been estimated that over $50 \%$ of the NVCNS exhibit an annual growth rate of more than $5 \%$ of the initial volume. This ratio is higher than in sporadic vestibular schwannomas, but lower than in patients with neurofibromatosis type 2 (NF2). ${ }^{6}$ Schwannomas usually remain benign, however there is a possibility of malignant transformation mainly in the setting of neurofibromatosis type 1 (NF1). ${ }^{5,7,8}$

The morbidity associated with skull base and intracranial schwannomas and their treatment has decreased with the improvement of open surgical approaches to 
the skull base and with the development of endoscopic skull base surgery. However, the morbidity of resection is still relatively high depending on the size and location of the tumor.

The purpose of this review is to discuss the latest trends in the management of these lesions in order to optimize disease control and quality of life.

\section{Trigeminal Schwannomas (TS) Epidemiology}

TS are a rare entity, accounting for $0.07-1 \%$ of all intracranial tumors. However, these tumors are the second most common intracranial schwannomas, after VS, and account for $3-9 \%$ of intracranial schwannomas. ${ }^{9-11}$ While most TS develop in the Gasserian ganglion within the middle fossa, TS can occur anywhere along the course of the trigeminal root, ganglion, and peripheral branches. Malignant TS are rare. Only 22 cases of histologically malignant TS have been reported in the literature. ${ }^{12}$ A review of 514 patients surgically treated for TS reported malignancy in $1.5 \%$ of them. ${ }^{9}$

\section{Classification Systems}

Several classification systems of TS have been employed, some of them are similar. The original classification of these tumors by Jefferson includes type A (mainly in the middle fossa), type B (mainly in the posterior fossa) and type $C$ (dumbbell type, in both the middle and posterior fossae). ${ }^{13}$ Type D was added later and includes those arising from one of the three divisions of the trigeminal nerve. ${ }^{12,14,15}$ In a review of 455 cases the following incidence was observed: $40 \%$ type A, $22 \%$ type B, 32\% type $\mathrm{C}$ and $6 \%$ type D. ${ }^{9}$ A more complex classification into 6 different types has been proposed by Yoshida and Kawase: ${ }^{16}$ type $\mathrm{P}$ (posterior fossa tumor); type $\mathrm{M}$ (middle fossa tumor); type E (extracranial tumor). The other 3 types refer to dumbbell type tumors in multiple fossae: type MP (middle and posterior fossae); type ME (middle fossa and extracranial space); type MPE (posterior fossa, middle fossa, and extracranial space). Employing this system, Yoshida and Kawase reported the location of 429 tumors: type M 38.5\%; type P 23.5\%; type E 5.4\%; type MP $28.3 \%$; type ME $3.5 \%$; and type MPE $0.7 \% .{ }^{16}$ In summary, TS arising in the middle fossa are the most common.

\section{Symptoms and Signs}

Trigeminal nerve dysfunction is seen in most patients. The most common trigeminal nerve symptoms are pain, paresthesia, numbness and decreased motor function. Symptoms and signs are reflected in Table $1 .^{9-12,15-20}$ However, it has been reported that up to $18 \%$ of tumors can be found incidentally with magnetic resonance (MR) imaging performed for other reasons. ${ }^{16}$

\section{Management}

Surgical resection is the mainstay of management, although the therapeutic modality used should be tailored individually according to tumor location and size, histology, patient comorbidities and symptoms. ${ }^{21}$

Table 1 describes the main open approaches. ${ }^{11,12,18,19,22,23}$ Lateral approaches via temporal craniotomy provide the shortest corridor to the Meckel's cave. ${ }^{12}$ Tumors originating intracranially from the second (V2) or third (V3) division of the trigeminal nerve are better approached through a subtemporal preauricular infratemporal fossa approach (Figure 1). ${ }^{22,23} \mathrm{In}$ tumors with a large extracranial component and anterior and inferior growth into the maxillary sinus, a facial translocation approach may be indicated (Figure 2). ${ }^{24,25}$ Transnasal endoscopic access to type A TS offers advantages similar to open skull base approaches in terms that there is no need for temporal lobe exposure or retraction with either technique, and both provide direct access to the tumor (Figure 2). Endoscopic approaches may provide a minimally invasive and safe approach to radically resect selected tumors.

Although the use of transpetrosal approaches for type B TS is under debate, the retrosigmoid approach is usually employed for posterior fossa tumors (Figure 1). ${ }^{11,12,18}$ In dumbbell shaped tumors (type C) with both posterior and middle fossa extension, in addition to a subtemporal approach a pre- or retrosigmoid craniectomy may provide additional exposure to resect. ${ }^{11,18}$

Schwannomas frequently do not invade nerve fibers but compress them. However, the nerve fibers are frequently adherent to the tumor. ${ }^{15}$ MRI sequences will soon allow preoperative determination of whether the trigeminal nerve fibers are medial or lateral to the tumor. Transcranial approaches might then be chosen for tumors that displace the trigeminal nerve medially while endonasal techniques may be selected for tumors displacing the nerve laterally. ${ }^{26}$

The treatment aims of TS focus on improvement in neurologic symptoms, relief of mass effect, and 
Table I Main Features of Non-Vestibular Intracranial Schwannomas

\begin{tabular}{|c|c|c|c|c|c|}
\hline Location & Frequency & Classification & Main Symptoms & $\begin{array}{l}\text { Other Symptoms } \\
\text { Signs }\end{array}$ & Surgical Approach \\
\hline TS & $\begin{array}{l}\text { 3-9\% of intracranial } \\
\text { schwannomas }\end{array}$ & $\begin{array}{l}\text {-Type A: middle fossa }(40 \%) \\
\text {-Type B: posterior fossa }(22 \%) \\
\text {-Type C: middle and posterior } \\
\text { fossae }(32 \%)\end{array}$ & $\begin{array}{l}\text { Pain }(23-95 \%) \\
\text { Paresthesia (36-46\%) } \\
\text { Numbness (10-76\%) } \\
\text { Decreased motor } \\
\text { function }(24-60 \%) \\
\text { Headache (14-43\%) } \\
\text { Abnormal corneal } \\
\text { reflex (36-72\%) }\end{array}$ & $\begin{array}{l}\text { Diplopia (10-52\%) } \\
\text { Oculomotor nerve } \\
\text { paresis }(5-40 \%) \\
\text { Exophthalmos (4-14\%) } \\
\text { Visual loss (5-24\%) } \\
\text { FN weakness (0-20\%) } \\
\text { Hearing loss (5-30\%) } \\
\text { Lower cranial nerves } \\
\text { deficit (5-18\%) } \\
\text { Cerebellar/pyramidal } \\
\text { system symptoms } \\
\text { (8-25\%) }\end{array}$ & $\begin{array}{l}\text {-Type A: transzygomatic extradural } \\
\text { temporopolar/EEA } \\
\text {-Type B: retrosigmoid } \\
\text {-Type C: transzygomatic frontotemporal } \\
\text { and retrosigmoid }\end{array}$ \\
\hline LCNS & $\begin{array}{l}-2.9-4 \% \text { of all } \\
\text { intracranial } \\
\text { schwannomas } \\
-10-30 \% \text { of tumors } \\
\text { of the JF }\end{array}$ & $\begin{array}{l}\text {-Type A: primarily intracranial } \\
(25-32 \%) \\
\text {-Type B: primarily within the JF } \\
\text { (15-22\%) } \\
\text {-Type C: primarily extracranial } \\
(12-15 \%) \\
- \text { Type D (dumbbell-shaped): } \\
\text { intra- and extracranial } \\
(40-68 \%)\end{array}$ & $\begin{array}{l}\text { Hearing loss }(45-84 \%) \\
\text { Headache }(15-27 \%) \\
\text { Dizziness }(15-23 \%) \\
\text { Dysphagia }(9-23 \%) \\
\text { Dysphonia }(9-21 \%) \\
\text { Tongue atrophy } \\
\text { (80-92\% of the HS) }\end{array}$ & $\begin{array}{l}\text { CN IX palsy }(30-40 \%) \\
C N \text { X palsy }(1 \mathrm{I}-27 \%) \\
\text { CN XI palsy }(9-17 \%) \\
\text { CN XII palsy }(15-18 \%) \\
\text { CN VII palsy }(8-18 \%)\end{array}$ & $\begin{array}{l}\text {-Type A: retrosigmoid } \\
\text {-Type B: modified infratemporal fossa } \\
\text { approach type A } \\
\text {-Type D: Infratemporal fossa/transcoclear } \\
\text { HS: far lateral/transcondylar }\end{array}$ \\
\hline FNS & $\begin{array}{l}\text { Less than } 1 \% \text { of all } \\
\text { intrapetrous } \\
\text { mass lesions }\end{array}$ & $\begin{array}{l}\text { Cerebellopontine angle } \\
\text { (18.7\%) } \\
\text { Canalicular segment }(24.9 \%) \\
\text { Labyrinthine/geniculate } \\
\text { segment }(43.6 \%) \\
\text { Tympanic segment }(42.2 \%) \\
\text { Mastoid segment }(35.8 \%) \\
\text { Peripheral segment }(14.6 \%) \\
\text { Chorda tympani }(1.1 \%) \\
\text { Stapedial nerve }(0.9 \%)\end{array}$ & $\begin{array}{l}\text { Facial weakness } \\
(62.5 \%) \\
\text { Hearing loss }(50.3 \%) \\
\text { Tinnitus }(20.6 \%) \\
\text { Vestibular symptoms } \\
(14.0 \%) \\
\text { Ear canal mass }(10.8 \%)\end{array}$ & $\begin{array}{l}\text { Pain }(8.0 \%) \\
\text { Otorrhea }(3.4 \%) \\
\text { Loss of taste }(2.8 \%) \\
\text { Parotid mass }(2.8 \%) \\
\text { Facial spasm }(2.1 \%)\end{array}$ & $\begin{array}{l}\text {-Retrosigmoid approach in CPA tumors } \\
\text {-Translabyrinthine approach in tumors } \\
\text { from the brainstem to the mastoid } \\
\text {-Middle cranial fossa approach for tumors } \\
\text { between IAC and the tympanic segment } \\
\text {-Transmastoid approach for tumors of the } \\
\text { tympanic and segments }\end{array}$ \\
\hline OMNS & & $\begin{array}{l}\text {-Cisternal } 42 \% \\
\text {-Cavernous } 30 \% \\
\text {-Cisterno-cavernous } 20 \% \\
\text {-Orbito-cavernous } 6 \%\end{array}$ & $\begin{array}{l}\text { Diplopia }(42 \%) \\
\text { Headache }(32 \%) \\
\text { Ptosis }(27 \%) \\
\text { Vision loss (13\%) }\end{array}$ & $\begin{array}{l}\text { Hemiparesis }(7 \%) \\
\text { Facial hypoesthesia } \\
(4 \%)\end{array}$ & $\begin{array}{l}\text {-Cisternal: subtemporal } \\
\text { transtentorial approach } \\
\text {-Cisterno-cavernous: subtemporal } \\
\text { transtentorial approach } \\
\text {-Orbito-cavernous: orbito-zygomatic } \\
\text { approach }\end{array}$ \\
\hline TNS & & $\begin{array}{l}\text { Cisternal type }>50 \% \\
\text { Cisterno-cavernous type } \\
\text { Cavernous type }\end{array}$ & $\begin{array}{l}\text { Diplopia }(76 \%) \\
\text { Paresis } \\
\text { Sensory changes } \\
\text { Ataxia } \\
\text { Other cranial nerve } \\
\text { palsies }\end{array}$ & & Subtemporal transtentorial approach \\
\hline ANS & & $\begin{array}{l}\text { Cisternal (33\%) } \\
\text { Cisternocavernous (24\%) } \\
\text { Cavernous sinus (27\%) } \\
\text { Caverno-orbital (3\%) } \\
\text { Intraorbital (12\%) }\end{array}$ & $\begin{array}{l}\text { Diplopia in horizontal } \\
\text { gaze } \\
\text { Headache } \\
\text { Proptosis } \\
\text { Other oculomotor } \\
\text { signs }\end{array}$ & $\begin{array}{l}\text { Trigeminal signs } \\
\text { Signs of intracranial } \\
\text { pressure }\end{array}$ & $\begin{array}{l}\text {-Lesions involving cavernous sinus: } \\
\text { frontotemporal transcavernous approach } \\
\text {-Cisternal lesions: retrosigmoid approach }\end{array}$ \\
\hline
\end{tabular}

(Continued) 
Table I (Continued).

\begin{tabular}{|l|l|l|l|l|l|}
\hline Location & Frequency & Classification & Main Symptoms & $\begin{array}{l}\text { Other Symptoms/ } \\
\text { Signs }\end{array}$ & Surgical Approach \\
\hline OGS & & & $\begin{array}{l}\text { Headache (53\%) } \\
\text { Seizures (41\%) } \\
\text { Anosmia (46\%) }\end{array}$ & $\begin{array}{l}\text { Diplopia } \\
\text { Signs of intracranial } \\
\text { pressure }\end{array}$ & $\begin{array}{l}\text { Transfrontal approach } \\
\text { EEA }\end{array}$ \\
\hline ONS & & $\begin{array}{l}\text { Cisternal } \\
\text { Optic canal }\end{array}$ & $\begin{array}{l}\text { Proptosis } \\
\text { Visual acuity } \\
\text { disturbance } \\
\text { Visual field defect }\end{array}$ & $\begin{array}{l}\text { Retro-orbital pain } \\
\text { Headache }\end{array}$ & $\begin{array}{l}\text { Transfrontal approach } \\
\text { EEA }\end{array}$ \\
\hline
\end{tabular}

Abbreviations: TS, trigeminal nerve schwannoma; LCNS, lower cranial nerves schwannoma; FNS, facial nerve schwannoma; OMNS, oculomotor nerve schwannoma; TNS, trochlear nerve schwannoma; ANS, abducens nerve schwannoma; OGS, olfactory groove schwannoma; ONS, optic nerve schwannoma; EEA, endoscopic endonasal approach; CN, cranial nerves; JF, jugular fossa; HS, hypoglossal schwannoma; SRS, stereotactic radiosurgery; CPA, cerebellopontine angle; IAC, internal auditory canal; HB, House-Brackman; CN, cranial nerves.

preservation of cranial nerve function. After the application of skull base techniques, gross total resection (GTR) has been achieved in $69-87 \%$. Near GTR $(4-26 \%$ of patients) or subtotal tumor resection (STR) $(7-21 \%$ of patients) are performed when there are difficulties dissecting tumor from cranial nerves, blood vessels, or the brainstem (Table 2). ${ }^{11,12,15,18,19,27}$ An improvement in facial pain post-operatively is seen between $45 \%$ and $100 \%$ of cases; ${ }^{12,15,18,19}$ trigeminal hypesthesia improved in $16 \%$ to $62 \% .^{12,15,18,19}$ Temporalis and pterygoid function will rarely, if ever, fully improve when present preoperatively. ${ }^{18,19}$ Other cranial nerve deficits, such as

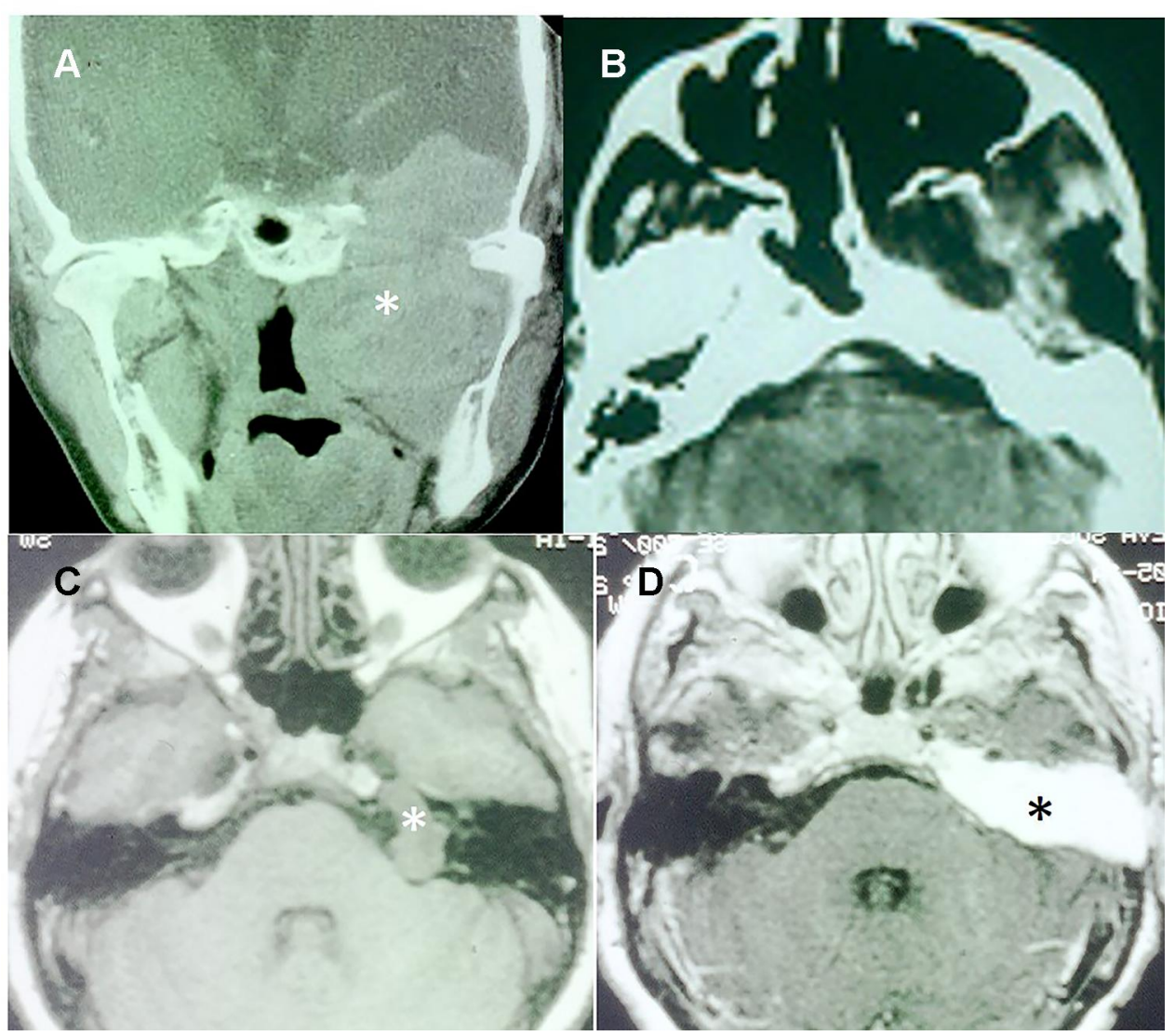

Figure I Surgical approaches in trigeminal schwannomas: subtemporal-preauricular and transcochlear. (A) Type ME2 TS with massive involvement of the middle cranial fossa and the infratemporal fossa $(*)$. (B) Postoperative CT showing the resection of the tumor through a subtemporal-preauricular approach. (C) TI-weighted MRI of a Type P TS in the posterior cranial fossa $\left(^{*}\right)$. (D) TI-weighted MRI with contrast showing total resection of the tumor through a transcochlear approach. The operative cavity is filled by fat $(*)$. 


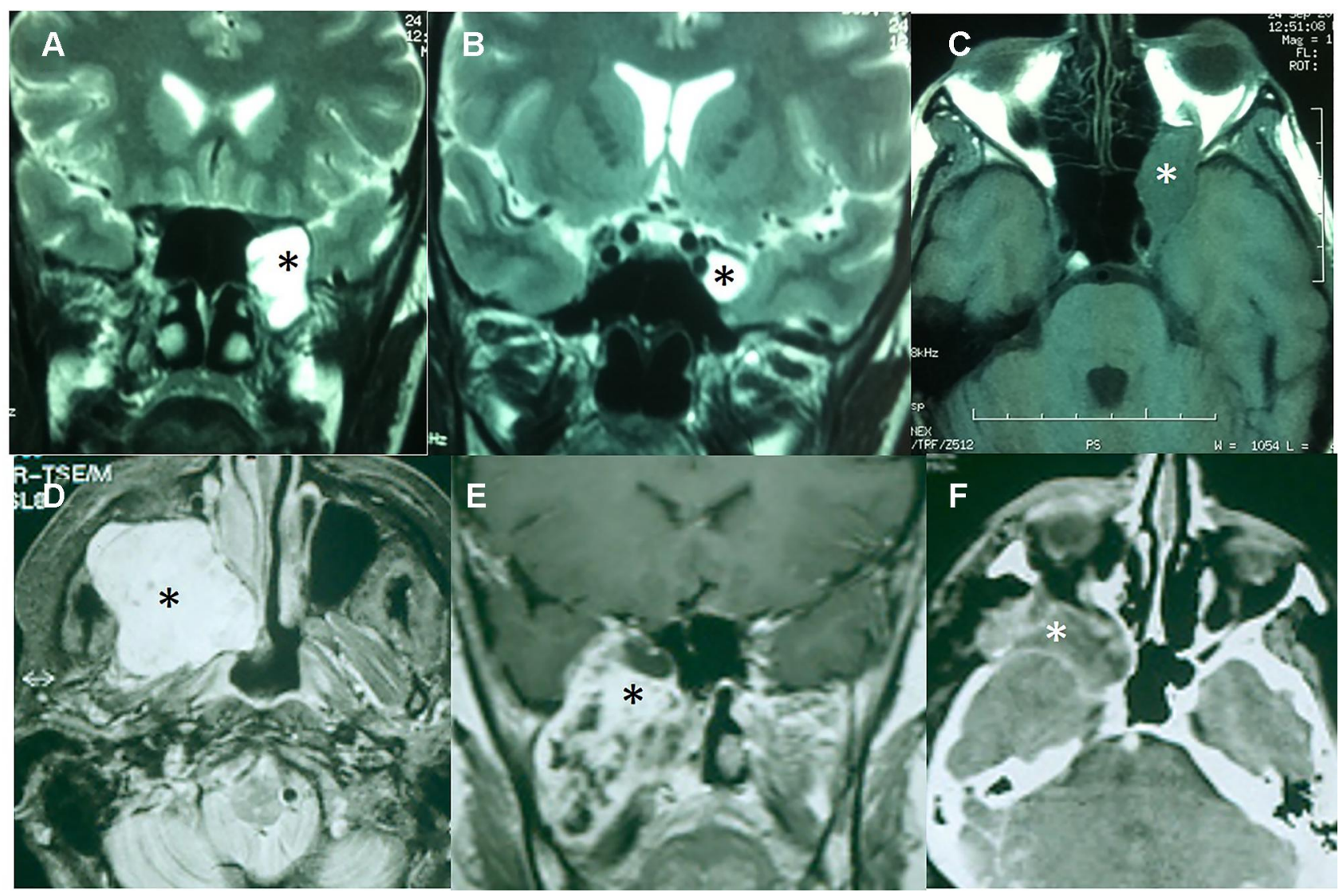

Figure 2 Surgical approaches in trigeminal schwannomas: EEA and facial translocation approach. (A) T2-weighted MRI of a Type MEI TS. The tumor is in contact with the transition between ethmoidal cells and the sphenoid sinus $(*)$. (B) Tumor into the Meckel's cave $(*)$. (C) Orbital progression in a TI-weighted MRI (*). This tumor was excised through an EEA. (D) TI-weighted MRI with contrast of an extensive dumbbell-shaped tumor (*) Type ME2 involving the middle and infratemporal fossae as well as the maxillary sinus. (E) TI-weighted MRI with contrast of a TS with a similar pattern of extension (*). (F) Postoperative CT scan of the anterior case showing the removal of the tumor. The operative cavity was obliterated with a temporalis muscle flap $(*)$.

diplopia caused by palsy of the abducens nerve, improved in $44-75 \%$ of patients, ${ }^{12,17-19}$ However surgical injury to the abducens nerve $(8 \%)$, trochlear nerve $(3.7 \%)$, and oculomotor nerve $(1.9 \%)$ has been reported. ${ }^{28}$ Long tract and cerebellar signs disappeared in $78-100 \% .^{15,17-19}$ Severe surgical complications are rare $(<2 \%$ of cases $)$ and include meningitis, cerebrospinal fluid (CSF) leak, arterial vasospasm, hematoma, and hydrocephalus. ${ }^{9,11,18,19}$ The overall mortality rates of surgical series reported since 1990 range from 0 to $3 \%{ }^{11,12,19,27,29,30}$ The sensory and motor outcomes of endoscopic approaches compare favorably with open surgical approaches. However, some patients may develop dry eye, as a result of vidian nerve sacrifice. ${ }^{31}$

Stereotactic radiosurgery (SRS) is an alternative to surgery. Most of series report a tumor control rate greater than $80 \%$, which is somewhat lower than that achieved with vestibular schwannomas. ${ }^{3,26,32-34}$ The incidence of tumor regression ranges from $34 \%$ to $87 \%$ and tumor stability from $8 \%$ to
50\%. ${ }^{32-37}$ A significant symptomatic improvement following SRS varies from $31 \%$ to $72 \%$ across the series, whereas the incidence of symptomatic deterioration varies from $0 \%$ to $27 \%{ }^{9}$ The factors affecting outcomes include tumor size and site, radiation dose and the radiological appearance of the mass (solid or cystic). The optimal tumor marginal dose appears to be $13-16$ Gy. SRS is associated with a very low risk of a new neurologic deficit or other type of complications (less than $16 \%$ of patients) (Table 3). ${ }^{32-37}$ There has been speculation regarding the risk of malignancy after treatment with SRS. With a median follow-up of 8.1 years, 2 of $3251(0.0006 \%)$ patients with benign tumors treated with SRS were diagnosed with suspected malignant transformation and 1 of 4905 $(0.0002 \%)$ patients was considered a case of radiosurgeryassociated intracranial malignancy, resulting in an incidence of 6.87 per 100,000 patient-years for malignant transformation and 2.26 per 100,000 patient-years for radiosurgery-associated intracranial malignancy, similar to the risk of developing a malignant CNS tumor in the general population. ${ }^{38}$ 
Table 2 Main Surgical Series of Intracranial Schwannomas

\begin{tabular}{|c|c|c|c|c|c|c|}
\hline Author & Location & $\begin{array}{l}\text { No. } \\
\text { Cases }\end{array}$ & $\begin{array}{l}\text { Total } \\
\text { Removal (\%) }\end{array}$ & $\begin{array}{l}\text { Near Total or Subtotal } \\
\text { Removal (\%) }\end{array}$ & $\begin{array}{l}\text { Increased or Newly } \\
\text { Developed Morbidity (\%) }\end{array}$ & $\begin{array}{l}\text { Mortality } \\
\text { (\%) }\end{array}$ \\
\hline Konovalov et al ${ }^{27}$ & $\mathrm{TN}$ & 111 & 77 & 23 & 13 & 3 \\
\hline Goel et al ${ }^{19}$ & $\mathrm{TN}$ & 73 & 70 & 30 & 31 & 2,7 \\
\hline Wanibuchi et al ${ }^{12}$ & $\mathrm{TN}$ & 105 & 75 & 25 & 9 & 0 \\
\hline Chen et $\mathrm{al}^{18}$ & $\mathrm{TN}$ & 55 & 69 & 31 & 5 & 0 \\
\hline Liu et al ${ }^{\prime \prime}$ & $\mathrm{TN}$ & 84 & 75 & 25 & 12 & 0 \\
\hline Yoshida \& Kawase ${ }^{16}$ & $\mathrm{TN}$ & 27 & 67 & 33 & 52 & 0 \\
\hline Sharma et $\mathrm{al}^{30}$ & $\mathrm{TN}$ & 68 & 76 & 24 & 15 & 1,5 \\
\hline Day \& Fukushima ${ }^{14}$ & $\mathrm{TN}$ & 39 & 77 & 23 & 16 & 0 \\
\hline Jeong et $\mathrm{al}^{29}$ & $\mathrm{TN}$ & 49 & 92 & 8 & 41 & 0 \\
\hline Cornelius et $\mathrm{al}^{55}$ & $\mathrm{FN}$ & 10 & 70 & 30 & 60 & 0 \\
\hline Sherman et $\mathrm{a}^{56}$ & $\mathrm{FN}$ & 10 & 90 & 10 & 20 & 0 \\
\hline Bakar $^{40}$ & LCN* & 199 & 79 & 21 & 38 & 0,5 \\
\hline Bulsara et $\mathrm{al}^{53}$ & LCN & 53 & 90 & 10 & 62 & 0 \\
\hline
\end{tabular}

Abbreviations: TN, trigeminal nerve; FN, facial nerve; LCN, lower cranial nerves. *Systematic review of 19 series.

Table 3 Main Stereotactic Radiosurgery Series of Intracranial Schwannomas

\begin{tabular}{|c|c|c|c|c|c|c|}
\hline Author & Location & $\begin{array}{l}\text { No. } \\
\text { Cases }\end{array}$ & $\begin{array}{l}\text { Decrease } \\
\text { Tumor Size (\%) }\end{array}$ & $\begin{array}{l}\text { Unchanged } \\
\text { Tumor Size (\%) }\end{array}$ & $\begin{array}{l}\text { Increase } \\
\text { Tumor Size (\%) }\end{array}$ & $\begin{array}{l}\text { Deterioration of } \\
\text { Symptoms (\%) }\end{array}$ \\
\hline Elsharkawy et al $\left.\right|^{32}$ & All locations NVCNS & 36 & 56 & 25 & 19 & 12 \\
\hline $\mathrm{D}^{\prime}$ Astous et $\mathrm{al}^{3}$ & All locations NVCNS & 63 & 57 & 35 & 8 & 6 \\
\hline Peker et $\mathrm{al}^{33}$ & $\mathrm{TN}$ & 15 & 87 & 13 & 0 & 7 \\
\hline Ryu et $\mathrm{al}^{34}$ & $\mathrm{TN}$ & 32 & 34 & 50 & 16 & 16 \\
\hline Snyder et $\mathrm{al}^{35}$ & $\mathrm{TN}$ & 22 & 54 & 23 & 23 & 16 \\
\hline Pan et $\mathrm{al}^{36}$ & $\mathrm{TN}$ & 56 & 85 & 8 & 7 & 7 \\
\hline Sun et $\mathrm{al}^{37}$ & $\mathrm{TN}$ & 52 & 77 & 10 & 13 & 4 \\
\hline Kida et $\mathrm{al}^{63}$ & $\mathrm{FN}$ & 14 & 57 & 43 & 0 & 7 \\
\hline Hasegawa et $\mathrm{al}^{62}$ & $\mathrm{FN}$ & 42 & 55 & 45 & 3 & 12 \\
\hline Hasegawa et $\mathrm{al}^{80}$ & LCN & 117 & 53 & 36 & 11 & 7 \\
\hline Kano et $\mathrm{al}^{79}$ & LCN & 92 & 51 & 36 & 13 & 15 \\
\hline Martin et $\mathrm{al}^{81}$ & LCN & 34 & 48 & 46 & 6 & 3 \\
\hline Peciu-Florianu et al ${ }^{65}$ & OMNS/TNS/ANS & 30 & 63 & 36 & 3 & 0 \\
\hline
\end{tabular}

Abbreviations: NVCNS, non-vestibular cranial nerves schwannomas; TN, trigeminal nerve; FN, facial nerve; LCN, lower cranial nerves; OMNS, oculomotor nerve schwannoma; TNS, trochlear nerve schwannoma; ANS, abducens nerve schwannoma.

Small lesions with few, if any, symptoms may be managed with watchful waiting. Makarenko et al observed 8 patients with TS; an $11.1 \%$ progressed over a median of 7.1 years. $^{39}$

\section{Lower Cranial Nerves Schwannomas (LCNS) Epidemiology}

Among NVCNS, LCNScomprise the second most common site after TS. LCNS can originate intracranially or in the cervical region. Intracranial LCNS usually extend to the jugular foramen or the hypoglossal canal. Jugular foramen schwannomas arising from cranial nerves IX, X or XI are rare and comprise $2.9 \%$ to $4 \%$ of all intracranial schwannomas, and represent $10-30 \%$ of all tumors observed around the jugular foramen. ${ }^{40,41}$ In a review of 204 patients, the tumor originated from the glossopharyngeal nerve (IX) in 47 cases $(23.6 \%)$, in 26 cases (13\%) from the vagal nerve (X) and in 11 cases $(5.5 \%)$ from the accessory nerve (XI). In the remaining $58 \%$ of the cases, the origin of the tumor remained unknown. ${ }^{40}$ Hypoglossal schwannomas (HS) constitute only about $1 \%$ of all intracranial schwannomas. ${ }^{42}$ 


\section{Classification}

Pellet et al classified jugular foramen schwannomas into 4 classes. ${ }^{43}$ Type A (primarily intracranial): minimal extension into the jugular foramen; type B (primarily within the bone): with or without an intracranial component; type C (primarily extracranial): only a minor extension into the jugular foramen or into the posterior fossa; and type D (dumbbell-shaped): intra- and extracranial extension. According to Pellet's classification, type Dschwannomas are the most common (40-68\%), followed by type A (25-32\%), type B (15-22\%) and type C $(12-15 \%){ }^{40,44}$

HS have been classified by Kaye et $\mathrm{al}^{45}$ in type A: intradural tumor; type B: dumbbell-shaped tumor; and type C: extracranial tumor. In 2 reviews of the literature consisting of 94 and 160 cases, the following distribution has been reported: type A, 29-32\%; type B, 39-50\%; and type C, $21-29 \%{ }^{42,46}$

\section{Symptoms and Signs}

Hearing impairment is the most frequent presenting symptom in intracranial and jugular foramen LCNS. ${ }^{40,41,43,47}$ Most of patients show a mid-frequency hearing loss, in contrast to the high-frequency hearing loss observed with VS. $^{47}$ Type A tumors may cause symptoms related to increased intracranial pressure, without or with minimal deficits of the lower cranial nerves, whereas a tumor expanding into the jugular foramen or upper cervical region might cause earlier damage of the nerves. ${ }^{41}$ Other presenting symptoms are shown in Table 1.

HS are characterized by tongue atrophy. Lower cranial nerves are affected in up to $50 \%$ of the cases, mainly in tumors with extension to the jugular foramen. ${ }^{45,46}$

\section{Management}

Schwannomas generally arise in nerves with a sensory component and are associated with sensory ganglia. In the case of the vagal nerve, tumors are likely to involve sensory nerves and it is possible to preserve their function with an intracapsular enucleation, which can increase the neural function preservation by more than $30 \%$. $^{7,48}$ Continuous vagal nerve monitoring during surgery is a new strategy developed with the aim of reducing postoperative morbidity. ${ }^{49}$

Table 1 summarizes the main surgical approaches used in LCNS resection according to their location. ${ }^{40,50-52}$ For tumors confined intracranially (type A), a retrosigmoid approach may provide adequate exposure (Figure 3). In tumors centered in the jugular foramen (type B) or with extracranial extension the modified infratemporal fossa approach type A (ITFA) provides the greatest exposure of the jugular foramen, carotid artery, and anterior temporal bone and it allows direct access to the posterior fossa (Figures 3 and 4). ${ }^{51,52}$ Other skull base techniques such as far lateral, transcondylar, and supracondylar approaches have been advocated for the surgical excision of HS (Figure 4). ${ }^{41,45,46}$

Bakar ${ }^{40}$ reviewed the outcomes obtained after the surgical treatment of 204 patients. He reported a GTR in $86.9 \%$ of the patients, near GTR in $3.3 \%$ of the patients and STR in $9.8 \%$ of the patients (Table 2). ${ }^{40}$ Park et al ${ }^{44}$ analyzed the results of surgery in 275 cases collected in large series of jugular foramen schwannomas and found postsurgical lower cranial nerve palsies in $34.9 \%$ of the patients. New neurological deficits are common, especially involving the facial nerve, which was reported in $6-34 \%$ of cases ${ }^{40,43,47}$ Other reported complications include CSF leak (3-7\%), aspiration pneumonia (1.5-6\%), venous sinus thrombosis (3\%), and meningitis (2\%). Postoperative mortality ranges between $0.5 \%$ and $5 \%{ }^{40,46,53}$

Near GTR followed by SRS or SRS alone offers an alternative approach in some patients (Tables 3 and 4). There are limited data based largely on extracranial schwannomas that fractionated external beam radiotherapy (RT) using doses of approximately 50 Gy at 1.8 Gy per fraction results in a high likelihood of local control. ${ }^{54} \mathrm{RT}$ usually induces cessation of lesion growth or reduction in size, rather than complete disappearance of the tumor, which is the goal of the surgical intervention. Side effects are negligible when doses are $50 \mathrm{~Gy}$ or less and modern precision RT techniques are used. This is additional option for patients requiring treatment who are unsuitable for surgery.

Observation is another option in asymptomatic patients, particularly for those who are elderly and/or infirm.

\section{Facial Nerve Schwannomas (FNS) Classification}

About 650 cases of FNS have been reported in the literature. ${ }^{55}$ The site of origin can be anywhere along the course of the facial nerve from the glial-Schwann cell transition site at the cerebellopontine angle to an extracranial peripheral nerve 


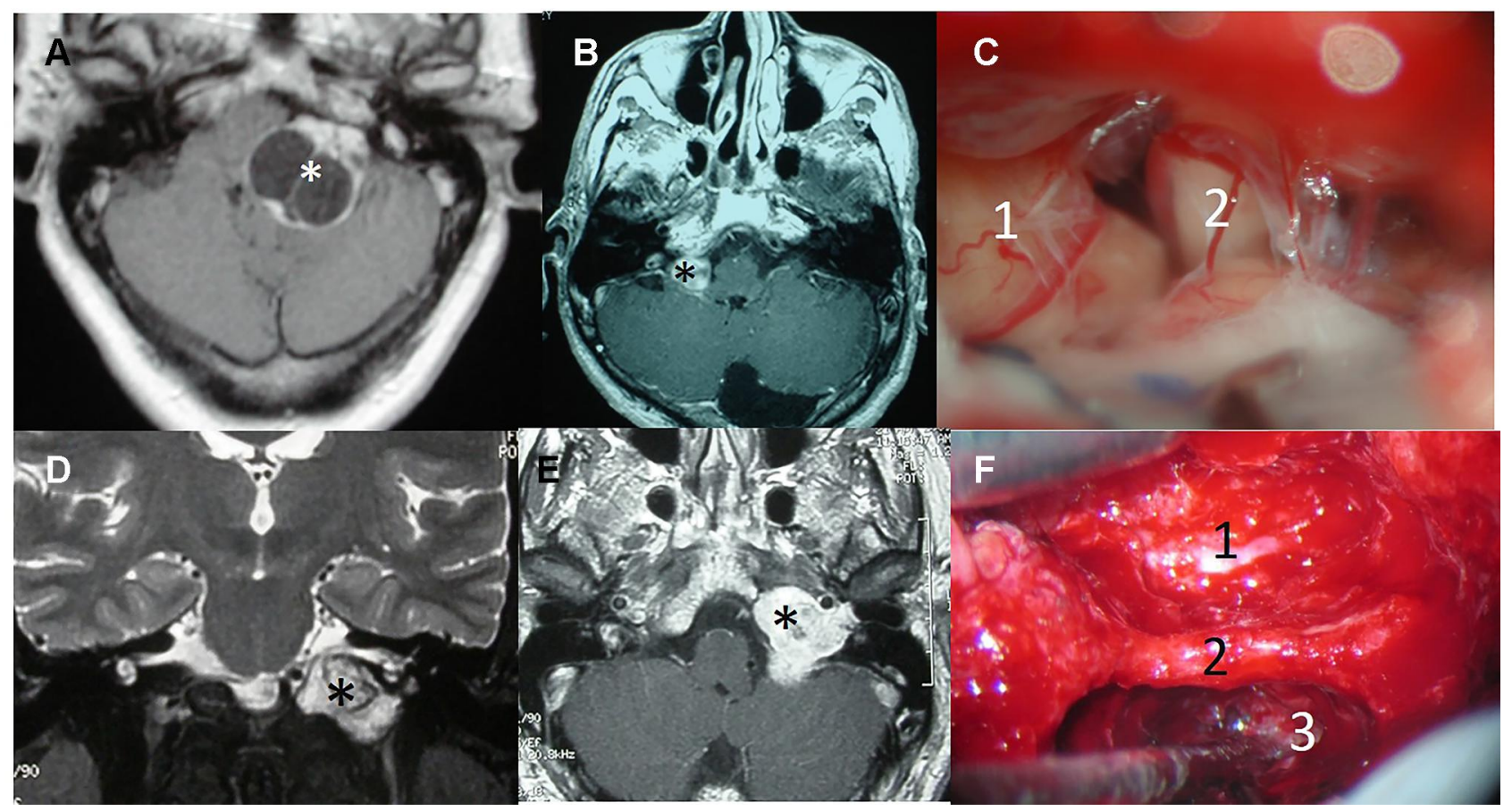

Figure 3 Surgical approaches in lower cranial nerve schwannomas. (A) TI-weighted MRI with contrast of a Type A cystic vagal schwannoma $(*)$. (B) TI-weighted MRI with contrast of a Type A vagal schwannoma (*). (C) Retrosigmoid approach of the last case showing the tumor (I) and the cochleo-vestibular nerve (2). (D) Coronal T2weighted MRI delimiting a Type B lower cranial nerve schwannoma in the jugular fossa $(*)$. (E) Axial TI-weighted MRI with contrast of the same tumor $(*)$. (F) Modified infratemporal fossa approach type (A) internal carotid artery (I), third portion of the facial nerve (2), tumor in the jugular fossa (3).

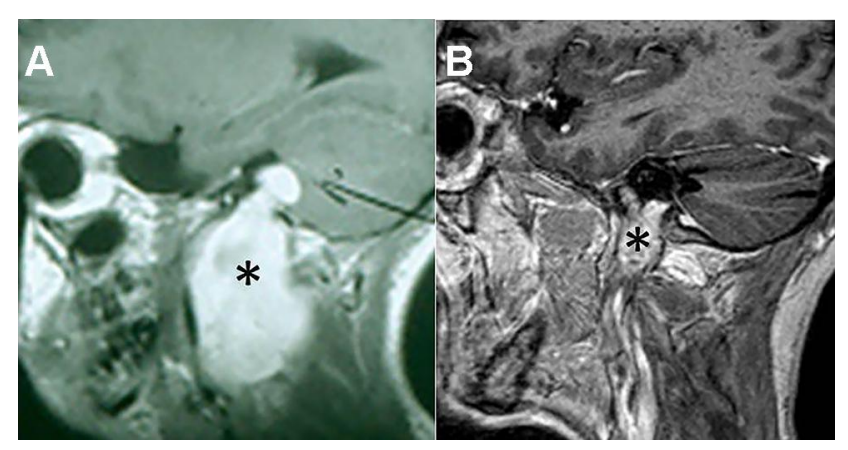

Figure 4 Lower cranial nerve schwannomas with intra- and extracranial extension. (A) TI-weighted MRI with contrast of a Type D vagal schwannoma (*). (B) TIweighted MRI with contrast of a Type B hypoglossal schwannoma (*).

location. They have been classified based on their site of origin into cerebellopontine angle (CPA), labyrinthine, geniculate, tympanic, mastoid, and parotid segments (Figure 5). ${ }^{56}$ The percentage involving each segment in a review of 438 cases was reported by Cornelius et al (Table 1). ${ }^{55}$

It is imperative to include FNS in the differential diagnosis of VS during preoperative planning and counseling. However, this is often difficult to achieve preoperatively, even with a careful evaluation of the MRI and computed tomography (CT). FNS involving the CPA and/or the IAC segment of the FN cannot be differentiated from a VS on imaging unless the tumor extends to the labyrinthine segment of the FN. Erosion of superior part of the internal auditory canal and eccentricity of tumor in relation to porus acousticus are not reliable signs. However, facial paralysis is a sign that would support the origin in the facial nerve since VS presenting with facial paralysis is rare.

\section{Symptoms and Signs}

The growth rate of FNS is slow. Thus, in a series of 13 patients treated expectantly with a mean follow-up period of 5 years, only 4 demonstrated tumor growth based on serial MRs. The average annual growth rate was $1.4 \mathrm{~mm} /$ year. $^{57}$

Patients frequently present with facial nerve weakness [House-Brackmann (HB) III or IV], as well as hearing loss. ${ }^{58-60}$ Tumors located at CPA usually present with sensorineural hearing loss (SNHL) and tinnitus instead of facial paresis. Patients with tumors originating from the labyrinthine segment tend to present with slowly progressive facial paresis and SNHL, whereas patients with tumors of the tympanic and mastoid segments show progressive facial paresis and conductive hearing loss. The 
Table 4 Radical Resection versus More Conservative Management

\begin{tabular}{|c|c|c|c|c|c|c|}
\hline Author & Location & No. Cases & Total Removal & $\begin{array}{l}\text { Subtotal Removal + } \\
\text { SRS }\end{array}$ & $\begin{array}{l}\text { Newly Developed Cranial } \\
\text { Nerve Palsies }\end{array}$ & Mortality \\
\hline Park et $\mathrm{al}^{44}$ & $\begin{array}{l}\mathrm{LCN} \\
\mathrm{LCN}\end{array}$ & $\begin{array}{l}22 \\
22\end{array}$ & 13 & 9 & $\begin{array}{l}23 \\
4\end{array}$ & $\begin{array}{l}0 \\
0\end{array}$ \\
\hline Author & Location & No. Cases & $\begin{array}{l}\text { Total Removal } \\
\%\end{array}$ & $\begin{array}{l}\text { Near Total or Subtotal } \\
\text { Removal \% }\end{array}$ & $\begin{array}{l}\text { Increased or Newly } \\
\text { Developed Morbidity \% }\end{array}$ & Mortality \\
\hline Sedney et $\mathrm{al}^{77}$ & $\begin{array}{l}\mathrm{LCN} \\
\mathrm{LCN}\end{array}$ & $\begin{array}{l}53 \\
28\end{array}$ & $\begin{array}{l}90 \\
24\end{array}$ & $\begin{array}{l}10 \\
76\end{array}$ & $\begin{array}{l}62 \\
25\end{array}$ & $\begin{array}{l}0 \\
0\end{array}$ \\
\hline Author & Location & No. Cases & $\begin{array}{l}\text { Total/Subtotal } \\
\text { Removal }\end{array}$ & $\begin{array}{l}\text { Conservative } \\
\text { Management }\end{array}$ & Worsened Facial Function \% & Mortality \\
\hline Liu \& Fagan ${ }^{82}$ & $\begin{array}{l}\text { FN } \\
\text { FN }\end{array}$ & $\begin{array}{l}22 \\
22\end{array}$ & 12 & 10 & $\begin{array}{l}50 \\
20\end{array}$ & $\begin{array}{l}0 \\
0\end{array}$ \\
\hline $\begin{array}{l}\text { McMonagle } \\
\text { et } \mathrm{al}^{83}\end{array}$ & $\begin{array}{l}\mathrm{FN} \\
\mathrm{FN}\end{array}$ & $\begin{array}{l}53 \\
53\end{array}$ & 33 & 20 & $\begin{array}{l}33 \\
15\end{array}$ & $\begin{array}{l}0 \\
0\end{array}$ \\
\hline
\end{tabular}

Abbreviations: FN, facial nerve; LCN, lower cranial nerves.

distribution of presenting symptoms in 438 patients with FNS is depicted in Table $1 .{ }^{55}$

\section{Management}

If the patient is asymptomatic and the tumor is small, conservative management with careful observation and followup with serial MRI are recommended. SRS may be an option for small and symptomatic tumors with good facial function (HB I or II). If the tumor is larger (more than $3 \mathrm{~cm}$ ) or the patient has facial palsy (HB III or worse), surgical resection should be considered. ${ }^{61}$ Alternatively, fractionated RT is an option if the anticipated morbidity of surgery is significant. The surgical approach depends on the tumor location and extent. The retrosigmoid approach permits access to the nerve from the brainstem to the IAC and allows resection of large tumors in the CPA. The translabyrinthine approach gives access to the entire nerve course from the brainstem to the stylomastoid foramen. This approach may only be chosen if hearing is not serviceable or if tumor volume or inner ear erosion makes hearing preservation impossible. A middle cranial fossa approach allows access to the nerve between IAC and the proximal tympanic segment. Combining this approach with a transmastoid approach the entire nerve from the IAC to the stylomastoid foramen can be exposed. Hearing preservation is possible by employing this route that make if possible, to repair ossicular chain defects. ${ }^{55}$
There are different options to preserve the facial nerve function: nerve conservation, nerve resection with immediate grafting, or hypoglossal-facial nerve anastomosis. ${ }^{59}$ Nerve preservation has been reported in $58-71 \%$ of the patients. ${ }^{55-57}$ However, facial nerve function was, in the majority of cases, a HB grade III, depending on surgical strategy (Table 2). ${ }^{58,60}$ Regardless of the type of facial nerve repair, patients can expect no better than an eventual HB grade III palsy. ${ }^{58,59}$

SRS achieves a good tumor control rates. ${ }^{62,63}$ Thus, a multi-institutional study reported 42 patients treated with SRS, with partial regression in 23 patients $(54.7 \%)$ and stability in 19 patients (45.2\%) (Table 3). The actuarial 5 -year progression-free survival rate was $92 \%{ }^{63}$

\section{Oculomotor Nerve Schwannomas (OMNS)}

\section{Classification}

There are only 54 cases of isolated OMNS reported in indexed literature. ${ }^{64}$ The transition of the oculomotor nerve from the central to the peripheral nervous system occurs $0.6 \mathrm{~mm}$ distal to the brainstem. OMNS develop distal to this transition zone. OMNS have been divided into 4 types based on their location: cisternal, cavernous, cisterno-cavernous, and orbito-cavernous (Table 1). ${ }^{65,66}$ 


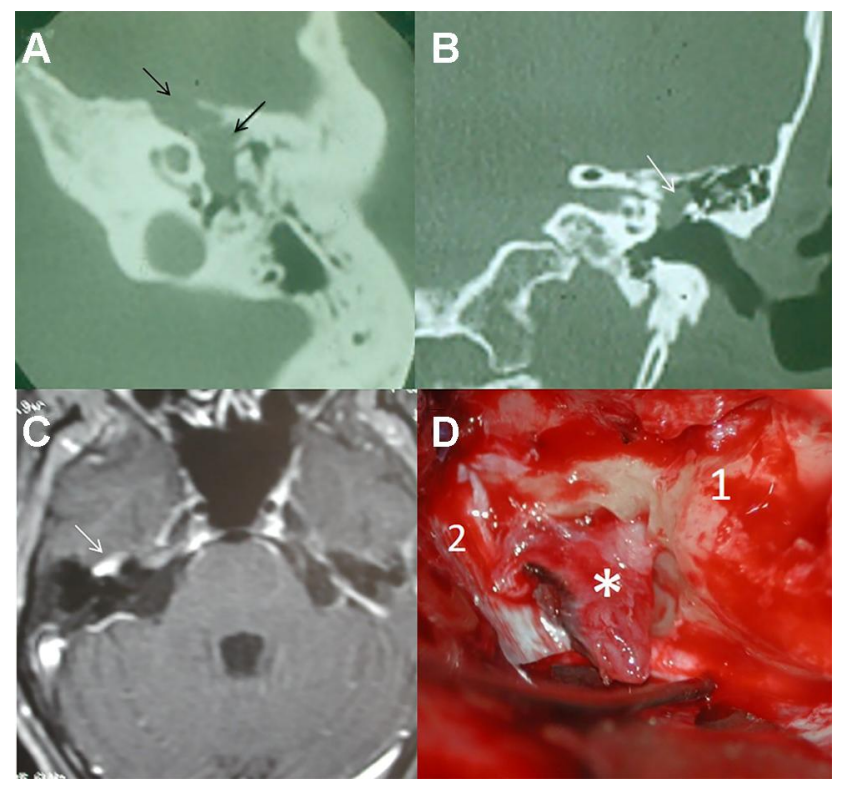

Figure 5 Facial nerve schwannomas. (A) The CT scan shows a tumor involving the tympanic and geniculate segments of the facial nerve (arrows), with displacement of the ossicular chain. (B) Small tumor limited to the tympanic segment (arrow). (C) TI-weighted MRI with contrast of a facial nerve schwannoma of the geniculate ganglion (arrow). (D) Transtemporal approach. Geniculate ganglion schwannoma $(*)$, petrous pyramid (I), dura (2).

\section{Symptoms and Signs}

The clinical features depend on the location of the tumor with cisternal schwannomas showing isolated deficits of the nerve. When these tumors originate into the cavernous sinus, they can present with either a cavernous sinus syndrome or an orbital apex syndrome. Symptoms can vary from incomplete oculomotor palsy and exophthalmos to brainstem compression signs. ${ }^{65}$ A systematic review has summarized the most frequent symptoms (Table 1). ${ }^{64}$

\section{Management}

Treatment for OMNS remains multimodal, depending on clinical presentation, tumor size, histology, and location. A careful preoperative evaluation including MR guides in distinguishing different histologies. Although most tumors arising from the oculomotor nerve are well encapsulated schwannomas and, in a few cases, nerve sparing surgery may be possible, neurofibromas have also been described. Neurofibromas tend to invade the entire nerve fibers and always require the complete sacrifice of the nerve. ${ }^{67}$

Often microsurgery remains the treatment of choice for the GTR of cisternal schwannomas after identification of the nerve of origin. However, when tumors are located in the cisternocavernous area, total removal of tumor and identification of the parent nerve is barely achieved in half of the cases and a combined approach with STR and SRS should be employed. ${ }^{68}$ Tumors with small-to-medium sized volumes are preferably treated by SRS with a high rate of tumor control and stabilization and/or improvement of symptoms. ${ }^{65}$

Functional recovery of the oculomotor nerve after STR is successful in less than $10 \%$ of the patients. Since the oculomotor nerve innervates multiple ocular muscles, the functional result after nerve anastomosis may be limited, and aberrant regeneration may interfere with coordinated binocular movements. ${ }^{64}$

\section{Trochlear Nerve Schwannomas (TNS) \\ Classification}

A total of 85 cases reporting on the management of TNS have been published. ${ }^{66}$ Three types of TNS have been described: cisternal type, cisterno-cavernous type, and the cavernous type. In more than half of the cases reported so far, the cisternal type was diagnosed. ${ }^{65,66}$

\section{Symptoms and Signs}

According to a systematic review from Torun et $\mathrm{al}^{66} 76 \%$ of the entire cohort presented with diplopia, which was the solitary symptom in over half of the cases, and $29 \%$ of cases presented with more severe symptoms, such as paresis, sensory changes, ataxia, and other cranial nerve palsies. ${ }^{66}$

\section{Management}

All symptomatic patients with a lesion exerting significant mass effect should undergo decompression. The most widely employed microsurgical approach has been the subtemporal transtentorial approach. Nevertheless, nearly $80 \%$ of those with surgical resection had persistent trochlear nerve palsy at the last follow-up.

SRS is a good option for patients presented with diplopia only, and $75 \%$ of the patients show improved symptoms after therapy. ${ }^{66}$

Patients who only have stable ocular misalignment due to trochlear nerve palsy can also be managed with prism glasses to alleviate diplopia or may choose to undergo strabismus surgery, combined with observation and serial MR imaging. ${ }^{66}$

\section{Abducens Nerve Schwannomas (ANS) \\ Classification}

ANS form an extremely rare entity with only 33 surgical cases published to date ${ }^{69}$ and 16 cases treated by SRS. ${ }^{65}$ The most common locations are shown in Table $1 .^{69,70}$ 


\section{Symptoms and Signs}

The cardinal neurological sign of ANS is diplopia in the horizontal gaze. However, patients may be asymptomatic or present with headache, proptosis, other oculomotor and/ or trigeminal signs, and signs of increased intracranial pressure. ${ }^{65}$ Involvement of other cranial nerves has been noted in over half the patients. ${ }^{69}$

\section{Management}

Surgical resection is indicated in symptomatic patients with neurological deficits, and most importantly to relieve any mass compression of surrounding structures. ${ }^{69}$ Extracavernous extension involving the orbital apex, superior orbital fissure and petroclival junction limits complete resectability. GTR with graft reconstruction of the abducens nerve has been recommended, ${ }^{69}$ but gross involvement of the cavernous sinus make more convenient to achieve a STR in order to avoid additional neurological damage. A frontotemporal transcavernous approach has been suggested for cavernous sinus and parasellar lesions, whereas the retrosigmoid approach is indicated for tumors involving the prepontine region. ${ }^{71}$ In a systematic analysis, Sun et $\mathrm{al}^{69}$ have reported abducens nerve recovery in less than half of the patients $(45 \%)$. Tumor extension to the cavernous sinus was significantly associated with a lower likelihood of postsurgical recovery.

SRS (single dose of 12.0-12.5 Gy) is recommended for small and moderate size tumors. Tumor volume was reported to remain stable in $18 \%$, reduced in $37 \%$, and increased in $12 \%$ of the patients, respectively (not reported in $31 \%$ ), treated with gamma knife SRS. ${ }^{65}$

\section{Olfactory Groove Schwannomas (OGS)}

\section{Histogenesis}

Thus far, only 46 cases with an OGS have been reported. ${ }^{8}$ Schwannomas of the olfactory bulb are uncommon as the olfactory nerve is unsheathed by Schwann cells. There have been various hypotheses proposed to explain the origin of OGS: the developmental hypothesis suggesting transformation of mesenchymal pial cells into ectodermal Schwann cells, and the non-developmental theory stating that these schwannomas may arise from Schwann cells of adjacent normal structures, such as Schwann cell hyperplasia occurring within the perivascular nerve plexuses. ${ }^{59,72}$ In contrast, neural crest cells have the ability to transform to other cells in the line or acquire abilities from some of these. ${ }^{73}$

\section{Symptoms and management}

In most reported cases of OGS, the chief complaints were headache, vomiting, seizure, diplopia, hyposmia or anosmia (Table 1). ${ }^{8,59}$

Surgery, either transfrontal or endoscopic, is the preferred treatment for olfactory schwannoma. GTR done by careful extra-arachnoidal dissection is possible as the tumor is well encapsulated and a plane of cleavage from olfactory tract is often present thus allowing preservation. $^{59}$

\section{Optic Nerve Schwannomas (ONS) Histogenesis}

Schwannomas partially located in the optic canal with an orbital and/or cisternal component are rare with only few cases reported, but those confined entirely within the optic canal are much rarer. As the optic nerve is in fact a part of the central nervous system, it is myelinated by central nervous system oligodendrocytes rather than Schwann cells. $^{1,74}$ ONS originate from ectopic Schwann cells around the optic nerve or from the sympathetic nerves around the optic nerve in the orbit, probably originating from peripheral sympathetic nerves innervating the central retinal artery or the carotid artery. 1,74

The microscopic appearance of schwannomas of the optic nerve is the same as for all schwannomas of peripheral nerve origin, thus distinguishing them from similar appearing lesions, such as optic nerve gliomas or meningiomas. Optic nerve sheath schwannomas probably cannot be diagnosed on clinical grounds alone, and their neuroimaging appearance mimics that of the more common optic nerve gliomas and the diagnosis is usually made at surgery. ${ }^{75}$

\section{Symptoms and Management}

Clinical presentation of lesions arising in the optic nerve is nonspecific and ranges from insidious proptosis, severe visual acuity disturbance and/or visual field defect, retroorbital pain and headaches, to in rare cases blindness. Since the optic canal is a narrow bony structure with a mean diameter of $4 \mathrm{~mm}$, the optic nerve can be compressed by even a tiny tumor.

The tumor can be approached extradurally by drilling the anterior clinoid and unroofing the optic canal. Orbital 
tumors may be safely and effectively resected via a various number of approaches. Currently, a transorbital endoscopic approach alone or combined with an expanded endoscopic endonasal approach is proposed as a method to improve visualization and maximize instruments' maneuverability. Nevertheless, traditional external approaches, with different skin or trans-conjunctival incisions, represent an effective and sound surgical option for the management of these lesions. $^{74,76}$ SRS would be not be indicated because of the risk of optic neuropathy associated with a single large fraction of irradiation. Patients unsuitable for surgery may be considered for fractionated proton irradiation to provide a high likelihood of tumor control while minimizing the dose to the retina.

\section{Discussion}

In the era of personalized medicine, trends in NVCNS management are giving way to a more individualized treatment plan based on the combination of surgery, radiation therapy and/or observation.

Because NVCNS are benign tumors, complete surgical excision while avoiding functional and aesthetic sequelae, is a primary objective. Despite the progress made in surgical approaches, resection is still associated with some morbidity in certain circumstances. The treatment goals for NVCNS are heavily dependent on the tumor presentation, location, histology and size. ${ }^{67}$ In addition, patient characteristics such as age and comorbidities must be taken into account. Not all patients should be operated, and surgery would not be an option if the risks are greater than those of a non-surgical treatment or observation. When dealing with tumors involving critical structures (i.e.: cavernous sinus, optic nerve, jugular fossa, etc.), whose damage has a significant impact on quality of life, management decisions must be individualized. Although some authors have reported improvement of symptoms with GTR, in most cases the presenting symptoms persisted or worsened after surgical resection. $^{31}$

In older and in asymptomatic patients with small tumors, when imaging studies and examination strongly suggest a benign tumor, close surveillance may be considered even without histological evidence, to avoid the risks inherent in biopsy or surgical resection. Likewise, asymptomatic patients with slow-growing small tumors should be managed with caution because they are at high risk of cranial nerve damage if operated on. In these cases, surgery should be avoided if it is expected to cause high morbidity. Gradual loss of nerve function is usually better tolerated than sudden loss as a result of surgery, so observation or deferral of surgery is recommended in patients without neurological alterations.

Safer treatment options have been proposed in some cases. RT has been used as either a primary or an adjunct treatment for NVCNS and offers the advantages of a high tumor control rate and a low rate of radiation associated complications. In contrast to surgical resection, injuries to the brain, vascular, or other cranial nerves are unlikely. SRS may offer therapeutic advantages over conventional RT, particularly logistically because it employs one fraction as opposed to 5 to 6 weeks of daily fractionated RT. Additionally, a tighter margin is employed with SRS so that less normal tissue is irradiated. Disadvantages of SRS are that the risk of a neurologic deficit may be higher due to the large dose per fraction and the risk of a marginal miss may be increased.

Patients with small- to moderate-sized tumors with intact cranial nerve function are optimal candidates for SRS. Furthermore, symptoms related to cranial nerve dysfunction may improve after SRS. In addition, patients with previous contralateral neurological deficits of the lower cranial nerves may not be suitable for surgery because of the risk that bilateral deficits will cause problems with swallowing and laryngeal mobility. In these cases, SRS may be useful. However, it is important to note that sometimes small-sized and slow-growing tumors are very symptomatic, and the symptoms are refractory to medical treatment (i.e., TNS refractory to carbamazepine). In these cases, surgical treatment is safer than follow-up or SRS. RT has been also used for patients who present large tumors or tumors affecting critical areas with high surgical morbidity. Residual tumor after surgery should be treated and SRS or RT are good options with acceptable morbidity.

When it is not possible to achieve a GTR because of technical operative difficulties or when surgery causes significant morbidity, STR or near GTR followed by SRS is gaining acceptance. Concerning TS, Pan et $\mathrm{al}^{36}$ reported that tumor growth control in 56 patients treated by using SRS, was obtained in $93 \%$ of the patients (including patients who had previously undergone STR). Cranial nerve preservation in patients with LCNS extending to the jugular foramen is challenging. Lower cranial neuropathies can severely affect quality of life requiring tracheostomy or gastrostomy. Park et $\mathrm{al}^{44}$ reported on 13 patients with LCNS treated with GTR and 9 patients 
treated by STR followed by SRS. In the latter group, 4 patients $(44 \%)$ showed a reduction in tumor size and 5 patients $(56 \%)$ showed no evidence of tumor progression. Postoperative $\mathrm{CN}$ deficits were higher in the GTR group (23 vs. 4 CNs affected, respectively). In addition, patients treated by STR and SRS showed a statistically significant improvement in the level of dysphagia. Sedney et $\mathrm{al}^{77}$ compared the outcomes of 53 LCNS patients who underwent a GTR with 28 patients receiving a more conservative resection. There was a statistically significant decrease in permanent deficits of $\mathrm{CN}$ IX/X with a conservative technique, whereas the recurrence rate was similar in both series (Table 4). The satisfactory clinical results obtained support that an appropriate strategy in the management of some LCNS is surgical resection to reduce tumor size followed by SRS in situations where GTR would likely cause significant morbidity. ${ }^{78-81}$ We believe that this alternative is potentially safe and effective and should be considered.

The best timing for surgery in FNS is controversial: it depends on facial nerve function, hearing, size, intracranial mass effect and patient choice. If hearing remains good and there is no threat from intracranial mass effect, observation until HB III is possible and radical tumor excision may be performed then. The reason is that even for good preoperative facial function (HB I-II) and regardless of the grafting technique, no better postoperative result than HB-III can be expected, although it is possible to preserve the nerve in approximately $25 \%$ of cases if the tumor is located eccentrically on the nerve. ${ }^{61}$ Liu and Fagan ${ }^{82}$ analyzed a series of 22 patients with FNS, of whom 12 underwent definitive excision and 10 were managed more conservatively. The best postoperative facial function in the group where the tumor was removal was a HB-III, while in the group treated conservatively, 8 had normal facial function. The role of "wait and see" approach has been evaluated by McMonagle et $\mathrm{al}^{83}$ in a series of 53 patients with FNS where 20 patients were managed conservatively and 33 underwent surgery. There was a GTR in 21 cases and near GTR was obtained in 12 cases. HB grade remained stable in all patients in whom no removal or STR was undertaken, while it worsened in $55 \%$ of patients receiving GTR. They conclude that observation is preferred until facial function deteriorates to a HB-III (Table 4). Another alternative is RT to avoid facial nerve deterioration and have a high likelihood of tumor control. Wilkinson et $\mathrm{al}^{84}$ reported a series of patients with FNS; through 1995, $85 \%$ of cases had surgical resection and none had observation only. Of the patients seen after $1995,27 \%$ had surgical resection and grafting, 33\% had bony decompression, 29\% were managed with observation alone, and $11 \%$ had RT. Facial nerve grade was maintained or improved over the follow-up period in $78.9 \%$ of the decompression group and $100 \%$ of the observation and RT groups, compared to $54.8 \%$ of the resection group $(\mathrm{P}<0.012)$. The trend is towards conservative management of these tumors.

\section{Non-vestibular skull base and intracranial schwannomas}
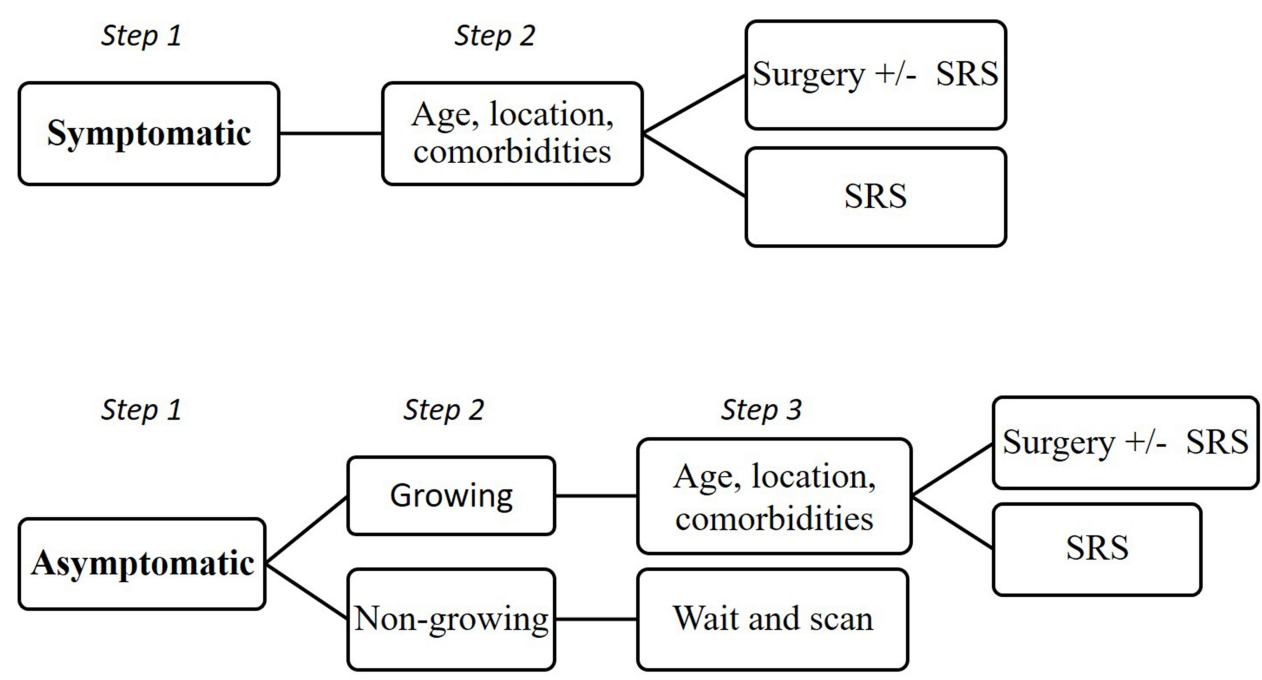

Figure 6 Steps in the management of non-vestibular skull base and intracranial schwannomas. 


\section{Conclusion}

NVCNS are rare tumors with a diversity of clinical manifestations, depending on the location and cranial nerve of origin. Management decisions are based on tumor size and functional deficits. The treatment of choice is total surgical resection, but SRS or RT are alternatives in those cases where surgical resection would be associated with substantial morbidity. Given the slow growth rate of most of these tumors, observation is also an alternative in asymptomatic patients (Figure 6).

\section{Acknowledgment}

This article was written by members and invitees of the International Head and Neck Scientific Group (www. IHNSG.com).

\section{Disclosure}

Johannes A Langendijk reports non-financial support from RaySearch, grants, personal fees, and consultancy fees paid to UMCG Research BV from IBA, and that the Department of Radiation Oncology has research collaboration with IBA, RaySearch, Elekta, Siemens, and VisionRT, outside the submitted work. The authors report no conflicts of interest in this work.

\section{References}

1. Ramey WL, Arnold SJ, Chiu A, Lemole MA. Rare case of optic nerve schwannoma: case report and review of the literature. Cureus. 2015;7 (4):e265. doi:10.7759/cureus.265

2. Evans DG, Bowers NL, Tobi S, et al. Schwannomatosis: a genetic and epidemiological study. J Neurol Neurosurg Psychiatry. 2018;89 (11):1215-1219. doi:10.1136/jnnp-2018-318538

3. D'Astous M, Ho AL, Pendharkar A, et al. Stereotactic radiosurgery for non-vestibular cranial nerve schwanommas. J Neurooncol. 2017;131 (1):177-183. doi:10.1007/s11060-016-2286-7

4. Colreavy MP, Lacy PD, Hughes J, et al. Head and neck schwannomas a 10 year review. J Laryngol Otol. 2000;114(2):119-124. doi:10.1258/ 0022215001905058

5. Guerrissi JO. Solitary benign schwannomas in major nerve systems of the head and neck. J Craniofac Surg. 2009;20(3):957-961. doi:10.1097/SCS.0b013e3181a14cbc

6. O'Reilly B, Mehanna H, Kishore A, Crowther JA. Growth rate of non-vestibular intracranial schwannomas. Clin Otolaryngol Allied Sci. 2004;29(1):94-97. doi:10.1111/j.1365-2273.2004.00770.x

7. Bondi S, Limardo P, Toma S, Bussi M. Non-vestibular head and neck schwannomas: a 10-year experience. Eur Arch Otorhinolaryngol. 2013;270(8):2365-2369. doi:10.1007/s00405-013-2520-2

8. Wang B, Yuan J, Chen X, Xu H, Zhou Y, Dong P. Extracranial non-vestibular head and neck schwannomas. Saudi Med J. 2015;36 (11):1363-1366. doi:10.15537/smj.2015.11.12314

9. MacNally SP, Rutherford SA, Ramsden RT, Evans DG, King AT. Trigeminal schwannomas. Br J Neurosurg. 2008;22(6):729-738. doi:10.1080/02688690802272172
10. Samii M, Migliori MM, Tatagiba M, Babu R. Surgical treatment of trigeminal schwannomas. $J$ Neurosurg. 1995;82(5):711-718. doi:10.3171/jns.1995.82.5.0711

11. Liu XD, Xu QW, Che XM, Yang DL. Trigeminal neurinomas: clinical features and surgical experience in 84 patients. Neurosurg Rev. 2009;32(4):435-444. doi:10.1007/s10143-009-0210-8

12. Wanibuchi M, Fukushima T, Zomordi AR, Nonaka Y, Friedman AH. Trigeminal schwannomas: skull base approaches and operative results in 105 patients. Neurosurgery. 2012;70(1Suppl Operative):132-143. doi:10.1227/NEU.0b013e31822efb21

13. Jefferson $\mathrm{G}$. The trigeminal neurinomas with some remarks on malignant invasion of the gasserian ganglion. Clin Neurosurg. 1953;1 (1):11-54. doi:10.1093/neurosurgery/1.CN_suppl_1.11

14. Day JD, Fukushima T. The surgical management of trigeminal neuromas. Neurosurgery. 1998;42(2):233-240. doi:10.1097/ 00006123-199802000-00015

15. Yang L, Hu L, Zhao W, Zhang H, Liu Q, Wang D. Endoscopic endonasal approach for trigeminal schwannomas: our experience of 39 patients in 10 years. Eur Arch Otorhinolaryngol. 2018;275 (3):735-741. doi:10.1007/s00405-018-4871-1

16. Yoshida K, Kawase T. Trigeminal neuromas extending into multiple fossae: surgical methods and review of the literature. $J$ Neurosurg. 1999;91(2):202-211. doi:10.3171/jns.1999.91.2.0202

17. Al-Mefty O, Ayoubi S, Gaber E. Trigeminal schwannomas: removal of dumbbell-shaped tumors through the expanded meckel cave and outcomes of cranial nerve function. $J$ Neurosurg. 2002;96 (3):453-463. doi:10.3171/jns.2002.96.3.0453

18. Chen LF, Yang Y, Yu XG, et al. Operative management of trigeminal neuromas: an analysis of a surgical experience with 55 cases. Acta Neurochir (Wien). 2014;156(6):1105-1114. doi:10.1007/s00701-014-2051-7

19. Goel A, Muzumdar D, Raman C. Trigeminal neuroma: analysis of surgical experience with 73 cases. Neurosurgery. 2003;52 (4):783-790. doi:10.1227/01.NEU.0000053365.05795.03

20. Ramina R, Mattei TA, Sória MG, et al. Surgical management of trigeminal schwannomas. Neurosurg Focus. 2008;25(6):E6. doi:10.3171/FOC.2008.25.12.E6

21. Dolenc VV. Frontotemporal epidural approach to trigeminal neurinomas. Acta Neurochir (Wien). 1994;130(1-4):55-65. doi:10.1007/BF01405503

22. Sekhar LN, Schramm VL Jr, Jones NF. Subtemporal-preauricular infratemporal fossa approach to large lateral and posterior cranial base neoplasms. J Neurosurg. 1987;67(4):488-499. doi:10.3171/ jns.1987.67.4.0488

23. Llorente JL, Nazar G, Cabanillas R, Fernández de León R, Suárez C. Subtemporal-preauricular approach in the management of infratemporal and nasopharyngeal tumors. $J$ Otolaryngol. 2006;35 (3):173-179.

24. Janecka IP, Sen CN, Sekhar LN, Arriaga M. Facial translocation: a new approach to the cranial base. Otolaryngol Head Neck Surg. 1990;103(3):413-419. doi:10.1177/019459989010300312

25. Suárez C, Llorente JL, Muñoz C, García LA, Rodrigo JP. Facial translocation approach in the management of nasopharyngeal and sinonasal tumors. Laryngoscope. 2004;114(6):1047-1051. doi:10.1097/00005537-200406000-00017

26. Niranjan A, Barnett S, Anand V, Agazzi S. Multimodality management of trigeminal schwannomas. J Neurol Surg B Skull Base. 2016;77(4):371-378. doi:10.1055/s-0036-1581138

27. Konovalov AN, Spallone A, Mukhamedjanov DJ, Tcherekajev VA, Makhmudov UB. Trigeminal neuromas: a series of 111 surgical cases from a single institution. Acta Neurochir. 1996;138(9):1027-1035. doi:10.1007/BF01412304

28. Raza SM, Donaldson AM, Mehta A, Tsiouris AJ, Anand VK, Schwartz TH. Surgical management of trigeminal schwannomas: defining the role for endoscopic endonasal approaches. Neurosurg Focus. 2014;37(4):E17. doi:10.3171/2014.7.FOCUS14341 
29. Jeong SK, Lee EJ, Hue YH, Cho YH, Kim JH, Kim CJ. A suggestion of modified classification of trigeminal schwannomas according to location, shape, and extension. Brain Tumor Res Treat. 2014;2 (2):62-68. doi:10.14791/btrt.2014.2.2.62

30. Sharma BS, Ahmad FU, Chandra PS, Mahapatra AK. Trigeminal schwannomas: experience with 68 cases. J Clin Neurosci. 2008;15 (7):738-743. doi:10.1016/j.jocn.2006.09.007

31. Shin SS, Gardner PA, Stefko ST, Madhok R, Fernandez-Miranda JC, Snyderman CH. Endoscopic endonasal approach for non-vestibular schwannomas. Neurosurgery. 2011;69(5):1046-1057. doi:10.1227/ NEU.0b013e3182287bb9

32. Elsharkawy M, Xu Z, Schlesinger D, Sheehan JP. Gamma knife surgery for nonvestibular schwannomas: radiological and clinical outcomes. J Neurosurg. 2012;116(1):66-72. doi:10.3171/2011.8. JNS11215

33. Peker S, Bayrakli F, Kiliç T, Pamir MN. Gamma-knife radiosurgery in the treatment of trigeminal schwannomas. Acta Neurochir (Wien). 2007;149(11):1133-1137. doi:10.1007/s00701-007-1285-9

34. Ryu J, Lee SH, Choi SK, Lim YJ. Gamma knife radiosurgery for trigeminal schwannoma: a 20-year experience with long-term treatment outcome. $J$ Neurooncol. 2018;140(1):89-97. doi:10.1007/ s11060-018-2934-1

35. Snyder MH, Shepard MJ, Chen CJ, Sheehan JP. Stereotactic radiosurgery for trigeminal schwannomas: a 28-year single-center experience and review of the literature. World Neurosurg. 2018;119:e874e881. doi:10.1016/j.wneu.2018.07.289

36. Pan L, Wang EM, Zhang N, et al. Long-term results of leksell gamma knife surgery for trigeminal schwannomas. $J$ Neurosurg. 2005;102:220-224. doi:10.3171/sup.2005.102.s_supplement.0220

37. Sun J, Zhang J, Yu X, et al. Stereotactic radiosurgery for trigeminal schwannoma: a clinical retrospective study in 52 cases. Stereotact Funct Neurosurg. 2013;91(4):236-242. doi:10.1159/000345258

38. Wolf A, Naylor K, Tam M, et al. Risk of radiation-associated intracranial malignancy after stereotactic radiosurgery: a retrospective, multicentre, cohort study. Lancet Oncol. 2019;20(1):159-164. doi:10.1016/S1470-2045(18)30659-4

39. Makarenko S, Ye V, Akagami R. Natural history, multimodal management, and quality of life outcomes of trigeminal schwannomas. J Neurol Surg B Skull Base. 2018;79(6):586-592. doi:10.1055/ s-0038-1651503

40. Bakar B. The jugular foramen schwannomas: review of the large surgical series. J Korean Neurosurg Soc. 2008;44(5):285-294. doi:10.3340/jkns.2008.44.5.285

41. Chibbaro S, Mirone G, Makiese O, Bresson D, George B. Dumbbellshaped jugular foramen schwannomas: surgical management, outcome and complications on a series of 16 patients. Neurosurg Rev. 2009;32(2):151-159. doi:10.1007/s10143-009-0188-2

42. Nonaka Y, Grossi PM, Bulsara KR, Taniguchi RM, Friedman AH, Fukushima T. Microsurgical management of hypoglossal schwannomas over 3 decades: a modified grading scale to guide surgical approach. Neurosurgery. 2011;69(2Suppl Operative):121-140.

43. Pellet W, Cannoni M, Pech A. The widened transcochlear approach to jugular foramen tumors. J Neurosurg. 1988;69(6):887-894. doi:10.3171/jns.1988.69.6.0887

44. Park ES, Lee EJ, Park JB, et al. A single-institution retrospective study of jugular foramen schwannoma. management: radical resection versus subtotal intracranial resection through a retrosigmoid suboccipital approach followed by radiosurgery. World Neurosurg. 2016;88:552-562. doi:10.1016/j.wneu.2015.10.042

45. Kaye AH, Hahn JF, Kinney SE, Hardy RW Jr, Bay JW. Jugular foramen schwannomas. $J$ Neurosurg. 1984;60(5):1045-1053. doi:10.3171/jns.1984.60.5.1045

46. Bindal S, El Ahmadieh TY, Plitt A, et al. Hypoglossal schwannomas: a systematic review of the literature. $J$ Clin Neurosci. 2019;62:162-173. doi:10.1016/j.jocn.2018.11.037
47. Vorasubin N, Sang UH, Mafee M, Nguyen QT. Glossopharyngeal schwannomas: a 100 year review. Laryngoscope. 2009;119(1):26-35. doi:10.1002/lary.20045

48. Behuria S, Rout TK, Pattanayak S. Diagnosis and management of schwannomas originating from the cervical vagus nerve. Ann $R$ Coll Surg Eng. 2015;97(2):92-97. doi:10.1308/003588414X140 55925058355

49. Sandler ML, Sims JR, Sinclair C, et al. Vagal schwannomas of the head and neck: a comprehensive review and a novel approach to preserving vocal cord innervation and function. Head Neck. 2019;41 (7):2450-2466. doi:10.1002/hed.25758

50. Sanna M, Mazzoni A, Saleh EA, Taibah AK, Russo A. Lateral approaches to the median skull base through the petrous bone: the system of the modified transcochlear approach. $J$ Laryngol Otol. 1994;108(12):1036-1044. doi:10.1017/S0022215100128841

51. Fisch U. Infratemporal fossa approach to tumours of the temporal bone and base of the skull. J Laryngol Otol. 1978;92(11):949-967. doi:10.1017/S0022215100086382

52. Suárez C, Sevilla MA, Llorente JL. Temporal paragangliomas. Eur Arch Otorhinolaryngol. 2007;264(7):719-731. doi:10.1007/s00405007-0267-3

53. Bulsara KR, Sameshima T, Friedman AH, Fukushima T. Microsurgical management of 53 jugular foramen schwannomas: lessons learned incorporated into a modified grading system. J Neurosurg. 2008;109(5):794-803. doi:10.3171/JNS/2008/109/11/ 0794

54. Kharod SM, Herman MP, Amdur RJ, Mendenhall WM. Fractionated radiation therapy for benign nonacoustic schwannomas. Am J Clin Oncol. 2018;41(1):13-17. doi:10.1097/COC.0000000000000219

55. Cornelius JF, Sauvaget E, Huy PT, George B. Surgical treatment of facial nerve schwannomas. Prog Neurol Surg. 2008;21:119-130.

56. Sherman JD, Dagnew E, Pensak ML, van Loveren HR, Tew JM Jr. Facial nerve neuromas: report of 10 cases and review of the literature. Neurosurgery. 2002;50(3):450-456. doi:10.1097/00006123200203000-00004

57. Perez R, Chen JM, Nedzelski JM. Intratemporal facial nerve schwannoma: a management dilemma. Otol Neurotol. 2005;26(1):121-126. doi:10.1097/00129492-200501000-00022

58. Lahlou G, Nguyen Y, Russo FY, Ferrary E, Sterkers O, Bernardeschi D. Intratemporal facial nerve schwannoma: clinical presentation and management. Eur Arch Otorhinolaryngol. 2016;273(11):3497-3504. doi:10.1007/s00405-015-3850-z

59. Deora H, Srinivas D, Beniwal M, Vikas V, Rao KVLN, Somanna S. Rare cranial nerve schwannomas: a retrospective review of nontrigeminal, nonvestibular cranial nerve schwannomas. J Neurosci Rural Pract. 2018;9(2):258-263. doi:10.4103/jnrp.jnrp_469_17

60. Lu R, Li S, Zhang L, Li Y, Sun Q. Stripping surgery in intratemporal facial nerve schwannomas with poor facial nerve function. $\mathrm{Am}$ $J \quad$ Otolaryngol. 2015;36(3):338-341. doi:10.1016/j. amjoto.2014.12.003

61. Xu F, Pan S, Alonso F, Dekker SE, Bambakidis NC. Intracranial facial nerve schwannomas: current management and review of literature. World Neurosurg. 2017;100:444-449. doi:10.1016/j. wneu.2016.09.082

62. Hasegawa T, Kato T, Kida Y, et al. Gamma knife surgery for patients with facial nerve schwannomas: a multiinstitutional retrospective study in Japan. J Neurosurg. 2016;124(2):403-410. doi:10.3171/ 2015.3.JNS142677

63. Kida Y, Yoshimoto M, Hasegawa T. Radiosurgery for facial schwannoma. $J$ Neurosurg. 2007;106(1):24-29. doi:10.3171/ jns.2007.106.1.24

64. Furtado SV, Hegde AS. Management of oculomotor nerve schwannomas in two different locations: surgical nuances and comprehensive review. Neurosurg Rev. 2012;35(1):27-34. doi:10.1007/s10143-0110344-3 
65. Peciu-Florianu I, Tuleasca C, Comps JN, et al. Radiosurgery in trochlear and abducens nerve schwannomas: case series and systematic review. Acta Neurochir (Wien). 2017;159(12):2409-2418. doi:10.1007/s00701-017-3348-0

66. Torun N, Laviv Y, Jazi KK, et al. Schwannoma of the trochlear nerve -an illustrated case series and a systematic review of management. Neurosurg Rev. 2018;41(3):699-711. doi:10.1007/s10143-016-0783$\mathrm{y}$

67. Matano F, Di Russo P, Okano A, et al. Oculomotor neurofibroma: a different histology implying an unsatisfying clinical outcome. World Neurosurg. 2020;139:31-38. doi:10.1016/j.wneu.2020.03.191

68. Celli P, Ferrante L, Acqui M, Mastronardi L, Fortuna A, Palma L. Neurinoma of the third, fourth, and sixth cranial nerves: a survey and report of a new fourth nerve case. Surg Neurol. 1992;38(3):216-224. doi:10.1016/0090-3019(92)90172-J

69. Sun H, Sharma K, Kalakoti P, et al. Factors associated with abducens nerve recovery in patients undergoing surgical resection of sixth nerve schwannoma: a systematic review and case illustration. World Neurosurg. 2017;104:883-899. doi:10.1016/j.wneu.2017.04.146

70. Iida Y, Sakata K, Kobayashi N, Tatezuki J, Manaka H, Kawasaki T. Orbital abducens nerve schwannoma: a case report and review of the literature. NMC Case Rep J. 2016;3(4):107-109. doi:10.2176/nmccrj. cr.2015-0259

71. Tung H, Chen T, Weiss MH. Sixth nerve schwannomas. Report of two cases. $J$ Neurosurg. 1991;75(4):638-641. doi:10.3171/ jns. 1991.75.4.0638

72. Sunaryo PL, Svider PF, Husain Q, Choudhry OJ, Eloy JA, Liu JK. Schwannomas of the sinonasal tract and anterior skull base: a systematic review of 94 cases. Am J Rhinol Allergy. 2014;28 (1):39-49. doi:10.2500/ajra.2014.28.3978

73. Mikkelsen LH, Heegaard S. Mucosal melanoma. In: Riker A, editor. Melanoma. Switzerland: Springer International Publishing; 2018:253-272.

74. Miyamura S, Yamaguchi S, Takeda M, et al. Pure intra-optic canal schwannoma: report of two cases. Asian J Neurosurg. 2017;12 (4):797-800. doi:10.4103/1793-5482.185071
75. Miller N. Primary tumours of the optic nerve and its sheath. Eye. 2004;18(11):1026-1037. doi:10.1038/sj.eye.6701592

76. Locatelli D, Dallan I, Castelnuovo P. Surgery around the orbit: how to select an approach. J Neurol Surg B Skull Base. 2020;81 (4):409-421. doi:10.1055/s-0040-1713893

77. Sedney CL, Nonaka Y, Bulsara KR, Fukushima T. Microsurgical management of jugular foramen schwannomas. Neurosurgery. 2013;72(1):42-46. doi:10.1227/NEU.0b013e3182770e74

78. Suri A, Bansal S, Sharma BS, et al. Management of hypoglossal schwannomas: single institutional experience of 14 cases. $J$ Neurol Surg B Skull Base. 2014;75(3):159-164. doi:10.1055/s-00331356924

79. Kano H, Meola A, Yang HC, et al. Stereotactic radiosurgery for jugular foramen schwannomas: an international multicenter study. J Neurosurg. 2018;129(4):928-936. doi:10.3171/2017.5.JNS162894

80. Hasegawa T, Kato T, Kida Y, et al. Gamma knife surgery for patients with jugular foramen schwannomas: a multiinstitutional retrospective study in Japan. J Neurosurg. 2016;125(4):822-831. doi:10.3171/ 2015.8.JNS151156

81. Martin JJ, Kondziolka D, Flickinger JC, Mathieu D, Niranjan A, Lunsford LD. Cranial nerve preservation and outcomes after stereotactic radiosurgery for jugular foramen schwannomas. Neurosurgery. 2007;61(1):76-81. doi:10.1227/01.neu.0000279726.90650.6d

82. Liu R, Fagan P. Facial nerve schwannoma: surgical excision versus conservative management. Ann Otol Rhinol Laryngol. 2001;110 (11):1025-1029. doi:10.1177/000348940111001106

83. McMonagle B, Al-Sanosi A, Croxson G, Fagan P. Facial schwannoma: results of a large case series and review. J Laryngol Otol. 2008;122(11):1139-1150. doi:10.1017/S0022215107000667

84. Wilkinson EP, Hoa M, Slattery WH 3rd, et al. Evolution in the management of facial nerve schwannoma. Laryngoscope. 2011;121 (10):2065-2074. doi:10.1002/lary.22141

\section{Publish your work in this journal}

Cancer Management and Research is an international, peer-reviewed open access journal focusing on cancer research and the optimal use of preventative and integrated treatment interventions to achieve improved outcomes, enhanced survival and quality of life for the cancer patient.
The manuscript management system is completely online and includes a very quick and fair peer-review system, which is all easy to use. Visit http://www.dovepress.com/testimonials.php to read real quotes from published authors. 